

\section{Third Sector Restructuring and the New Contracting Regime: The Case of Immigrant Serving Agencies in Ontario}

Ted Richmond (Children's Agenda Programme Co-ordinator, Laidlaw Foundation)

$\&$

John Shields (Associate Director, Centre of Excellence for Research on Im migration and Settlem ent - Toronto (CERIS) \& Professor, School of Public Administration, Ryerson University) 


\begin{abstract}
Many are aware of declining capacity in the NGO sector with respect to advocacy and community development, but to date there has been relatively little analysis of the causes and consequences of this alarming trend. As this paper will demonstrate, however, much more is at work in the serviceproviding sector than simple "overload" due to expansion of service demands beyond available funding.

We will document and analyse the ways that the NGO service sector in Canada, and with Ontariobased immigrant serving agencies in particular, are being deliberately restructured through the shift from "core" to "program" funding, the de-legitimization of community development work as a fundable service, and the imposition of complex and burdensome accountability schemes disguised as evaluation measures. We will also examine the consequences of this restructuring in terms of growing monopolisation within the sector and the consequent reduction of diversity of service alternatives, as well as reduced capacity for public education and community development.

The paper will explore the paradox inherent in the fact that such restructuring is being imposed without public debate in the name of the public good, and propose potential solutions related to this crucial issue of Canadian public policy. As essential background to the analysis we will provide an overview of the growing and changing role of the "third sector" as the preferred delivery agent for human services within a downsized and globalized economy.
\end{abstract}




\section{Author Biographies}

Ted Richmond is the Children s Agenda Programme Co-ordinator for the Laidlaw Foundation in Toronto. Previously he worked as the Programme Manger at the Community Social Planning Council of Toronto and as the Coordinator at the CERIS immigration research centre in Toronto, and prior to that as Research Coordinator at the Ontario Council of Agencies Serving Immigrants (OCASI).

Ted has a Master's degree in measurement and evaluation from Ontario Institute for the Study of Education (OISE), University of Toronto. He has done extensive publishing and speaking on the topic of appropriate evaluation methods for community organizations, including presentations at the annual meeting of the Canadian Evaluation Society (Montreal, 2000) and the National Settlement Conference (Kingston, Ontario 2001). Ted has also been actively involved for many years with developing community-based research capacities, and effective NGO use of the new technologies; in this capacity has served on numerous community boards and advisory committees.

John Shields is a Professor of Politics and Public Administration at Ryerson University and an Associate Director with the Joint Centre of Excellence for Research on Immigration and Settlement - Toronto (CERIS). He has published extensively in the areas of Canadian public policy and public administration focusing on labour market, third sector and welfare state change. He has co-authored four books and over twenty published articles and papers. His most recent books are: Restructuring and Resistance: Canadian Public Policy in an Age of Global Capitalism (co-edited with Mike Burke and Colin Mooers) Halifax: Fernwood, 2000; Shrinking the State: Globalization and the "Reform" of Public Administration (with B. Mitchell Evans) Halifax: Fernwood, 1998; Dismantling a Nation: The Transition to Corporate Rule in Canada, 2nd edition (with Stephen McBride) Halifax: Fernwood, 1997. 


\section{1) Introduction: The State, NGOs and Contract Funding - Building Better Partnerships?}

While many are aware of declining capacity in the NGO sector with respect to advocacy and community development, to date there has been relatively little analysis of the causes and consequences of this alarming trend ${ }^{1}$. These developments have profound and indeed disturbing implications for inclusive citizenship, the health of civil society and the development of cohesive communities.

As we demonstrate in this paper, much more is at work in the NGO service-providing sector than simple "overload" due to expansion of service demands beyond available funding, although the overload is a real and important factor in the crisis. The "third sector" has become the preferred delivery agent for human services within a downsized and globalized economy, and over the past number of decades governments have been restructuring their relationships with nonprofit organizations, including those with immigrant serving agencies (ISAs) ${ }^{2}$. While this restructuring has taken place under the inclusive title of 'building partnerships', in actual fact the kinds of relationships that have generally been fostered are top-down, contractual ones. This shift from "core" to "program" financing involves, among other factors, the de-legitimization of community development work and public education as a fundable activities, and the imposition of complex and burdensome accountability schemes disguised as evaluation measures. The contractual relationship that is being developed between the state and nonprofit organizations is, in effect, serving to transform the nonprofit sector, moving it away from its core mission, commercializing the sector's operations and compromising its autonomy.

${ }^{1}$ Earlier studies of the implications of social service restructuring for NGOs missions and advocacy efforts include Creese (1998) and Mwarigha M.S. and Murphy (1997). The Canada West Foundation (1999b), from a private sector perspective, has also provided an analysis of the alarming implications of increasing government control of voluntary sector activities through funding restrictions.

The Institute for Media, Policy and Civil Society (IMPACS) has been involved in a major campaign around the restrictions on advocacy for charitable organizations associated with Canada's tax laws. This is an important issue, but not the subject of this paper. For further information see $<$ www.impacs.org $>$.

${ }^{2}$ Note: Much of the analysis in this paper is based on the limited number of general studies on non-profits located in the social service sector in Canada, including a number of recent studies which are cited. Many of the specific examples refer to the situation of the immigrant service agencies (ISAs), with which the authors are most familiar. Although there are very few studies concerning the effects of restructuring on the immigrant serving agency (ISA) sector as such. However, evidence suggests that trends found in ISAs broadly mirror those found in the larger NGO sector. 
Rather than promoting civil society and democracy through the strengthening of community voices, these new 'partnerships' have tended to work against these goals. There is a fundamental paradox inherent in the fact that such restructuring is being imposed without public debate in the name of the public good, and resolution of this paradox is a fundamental issue of Canadian public policy. In the concluding section of this paper we will present considerations towards practical solutions, as well identifying some issues requiring further analysis and debate.

\section{2) Setting the Context}

\section{i) Gaps in Our Knowledge Base: The State of NGO Research}

Up until very recently the nonprofit sector has been a largely hidden world. Serious study or adequate knowledge and acknowledgement of the role and contributions of the nonprofit community-based organizations were absent. In more recent years this situation has begun to be rectified. There is still, however, a considerable way to go. Building the knowledge base of the nonprofit sector remains an important object. The primary reason for this lies not in an academic need for advancing knowledge for knowledge's sake - although this is a noble objective on its own - but rather because without more information about the structure, composition, relationships in that exist in the sector, and its contributions, nonprofits are unlikely to be given the support and recognition they deserve and need in order to play a constructive and expanded role within society. Judith Maxwell vividly describes the situation in the following terms:

To be blunt, the state of knowledge at this time is primitive. Our frameworks and data are perhaps at the level of the national economic accounts and public sector accounts of almost a century ago. We have a lot of numbers and some interesting analytical studies, but they are incomplete. They yield an X-ray - a rough sketch of the bare bones. What we need, in the longer term, is an MRI scan that displays the soft tissue of the sector - the ligaments that tie the bones together and the muscles that give them force and direction (1997: vii-viii).

Among the most important work which remains to be done is in the area of alternative indicators of wealth and well-being. Part of the problem rests not just in the inadequate collection of standard statistical measures on nonprofit organization and their activities, but the quality and utility of the measures themselves. Many of the activities which nonprofits are engaged in do not lend themselves to standard measures and hence go unaccounted. For example, while we know that volunteering adds important value to our economy and society, because it is not paid work (much like house work) it is not added into the calculation of the Gross Domestic Product (GDP), the official measure of the value of the wealth created within the country. Much of the value 
created by the voluntary sector is like this ${ }^{3}$. Also while it is relatively easy to count the number of contacts a nonprofit agency may have with clients, measuring the quality and value added of those interactions is far more challenging. There is a "growing recognition of the difference between monetary transactions and a genuine addition to the nation's well being" (White 1996: 6). If the value of nonprofit organizations contribution to society is to be fully recognized significantly more work on, and acceptance of, alternative measures/indices will need to happen. These measurement challenges, including the issues of what comes to be measured in the first place and how it is valued, have important implications, as we will see, for the new contractual relationships that have come to be established between the state and nonprofit organizations.

Currently there is a lack of a comprehensive survey of the size, scope and health of the nonprofit sector as a whole, and even less is know about the sub-sectors, including settlement services. What we do know comes from a variety of scattered sources. Firstly, a very limited number of semi-quantitative, although not necessarily representative in the broad sense, of mostly locally or regionally based, surveys (see for example: Clutterbuck and Howarth 2002; Reed and Howe 2000; Canada West Foundation 1999a \& 1999b; United Way of Greater Toronto 1997; and Metro Toronto Community Services 1995); secondly, some case studies, generally qualitative in orientation (see for example: Owen 2000; Creese 1998; Mwarigha and Murphy 1997; and Ng 1996); and finally, various more informal reports from the frontline that have been communicated at assorted gatherings of service providers. These sources provide a good sense of the 'lived' impact of restructuring in the sector but for a more comprehensive understanding we will require more detailed and empirical analyses. In short, there exist a significant knowledge gap concerning even some of the more basic characteristics of the sector, a situation that hinders our ability to comprehend the needs and stresses faced by the sector in a more holistic way.

\section{ii) NGOs and the Political Economy of Change}

An environmental scan of the major external transformations over the last couple of decades that have significantly affected nonprofit community organizations reveals two main areas of change; namely, public sector restructuring and socio-economic developments associated with globalization and the politics of competitiveness. In short, the political and economic environment over this time frame has altered dramatically. Certainly, one of the greatest changes and challenges confronting the voluntary/nonprofit sector is the formidable shifts which are occurring in the role that government is expected to play within society. At a number of levels this is having an impact on the ability of nonprofit organizations to deliver their services, as well as, influencing the scope and nature of the role which nonprofits are expected to play within society.

A devolving of the role of government - i.e., the shrinking of the size and scope of

3 For an intriguing discussion of the problems traditional measures of society's wealth and how they are failing to capture current realities see The Atlantic Monthly article by Clifford Cobb, Tedd Halstead and Jonathan Rowe "If the GDP is Up, Why is America Down?" (1995). 
government and the shifting of state responsibility downward and onto other bodies — has been going on since the 1970s. However, in the 1990s the pace of government devolution of responsibilities has accelerated, placing greater pressure on society to address the consequences of the state's retreat from many of the functions and services which it had provided to society. The general trend has been to shift responsibility downwards with the municipalities experiencing the most negative impacts among Government bodies. Cities have been saddled with greatly expanded responsibilities without the benefit of an adequate funding/tax base. However, following from the call from Osborne and Gaebler's Reinventing Government (1992), for Government to steer rather than row, there has been an even stronger shift to contract out service delivery to nonprofits and in some cases for-profit organizations. The outstanding remaining questions are whether nonprofit organizations and volunteers can handle these enhanced responsibilities, will the state and other societal actors assist in improving the resource base required for nonprofits to assume a greater role, and how might nonprofits be transformed in the process?

At the same time as greater expectations are being placed on nonprofit organizations to fill the gaps in services left by a retreating state, demand for many of those services has rapidly increased brought on by the problems fostered by a dramatically restructured social and economic environment. Levels of income polarization (Canadian Council on Social Development 2003; and Burke and Shields 2000), poverty, homelessness (Evans 1998) and youth exclusion (Marquardt 1998) have deepened. Recent immigrants, despite higher education and skill qualifications upon arrival, have seen their labour market position deteriorate. Statistics Canada points to a $25 \%$ earnings deficit (Statistics Canada 2003) compared to both native-born earners and older cohorts of immigrants. There is also growing evidence of the racialization of poverty in the larger cities, especially in the case of Toronto (Ornstein 2000; Galabuzi 2001, United Way of Greater Toronto \& Canadian Council on Social Development 2002; Shields 2003). These trends point to significant problems in the economic integration of some of our most vulnerable populations. ${ }^{4}$ The intersection of these difficulties tend to have a compounding effect on the demand for services. These problems are expanding in part because of the ongoing erosion of the Canadian social safety net (Russell 2000; and McBride and Shields 1997) and the side effects of economic globalization and rapid technological change. Once again the question of the capacity of the nonprofit sector to cope with such increased demand is raised (see for example: Hall and Reed 1998).

3) The New Contracting Regime: Wither Community-Based Advocacy and NGO Autonomy?

i) Overview

${ }^{4}$ Utilizing a neoliberal basis of rational a call has been made to limit immigrant numbers and to shift the character of Canadian recruitment patterns (see: Collacott 2002; Francis 2002; and Stoffman 2002). This approach to the immigration question has played into a right-wing political agenda as demonstrated in the 2003 Ontario provincial election where the governing Progressive Conservatives in their election platform linked immigrants with their anti-crime agenda. 
The drive towards alternative service delivery (ASD) arrangements increasingly calls upon third sector actors to enter into partnerships with the state. These arrangements are overwhelmingly focussed upon production of services. Advocacy through intermediary nonprofit organizations, under the rules of this new funding regime, has been actively discouraged (Laforest 2001: 8). Hence, other important roles served by the third sector, such as research and advocacy, are marginalized.

It has been suggested that agencies 'partnering' with government have attained policy access through, if you will, the back door - i.e., that such organizations have gained access and policy credibility through this partnering role (Laforest 2001: 14). However, there is little evidence to support the notion that the voice of such groups on policy matters is being heard in any meaningful way — after all the sector has been subject, through this whole process, to significant cuts and a painful process of forced restructuring.

Research and advocacy functions play an obviously important role in the larger issue of policy development. This is of particular importance when Canadian governments at the federal and provincial levels are seeking to build their respective policy capacities through network and policy community building. Ironically, with respect to the nonprofit sector, the role being established for it as producers governed by contractual arrangements with the state curtails their autonomous capacity to offer alternative perspectives. Reports from the field offer 'lived' evidence of the negative effects of the engagement in advocacy activities for the success in securing government service contracts (Social Planning Council of Ottawa-Carleton 2001: 24). The contract relationship can result in nonprofits losing their "political edge" and ability "to work for political change". Moreover, while contemporary governments speak the language of civic engagement there remains a strong bias left over from an earlier era which tends to view voluntary organizations as simply charities charged with the mission of helping the needy and promoting moral reform. Consequently, as Susan Phillips notes: "there is still a hold-over assumption that the voluntary sector exists primarily to provide services and, related to this, that there is limited need for representatives of these organizations to participate in broader public policy debates" (2003: 23). This is hardly the kind of environment that is nurturing of a vibrant civil society and pluralist democracy (Canada West Foundation 1999b: 11).

Restructuring of the nonprofit sector is resulting in the commercialization of nonprofit activities and the loss of autonomy of the sector, as nonprofit organizations become ever more tied to government controlled service contracts. In the process the services offered by the third sector are being transformed. "Many of the so-called partnerships are, in fact, merely contracts in which the state, as the contracting party, sets all the rules" (Jenson and Phillips 1996: 127).

Increasingly fees for services are being introduced, as is 'rationalization', mergers, and 'professionalization' of services, which is moving the quality of nonprofit services away from its community and personal touch. Community involvement in the running of nonprofit service provision is, in many instances, being replaced by professional management and a accountability 
to the state rather than to the community ${ }^{5}$. Moreover, the drive to download responsibilities for social welfare by governments to the third sector has strained the capacity of the sector to handle new demands to its outer limits.

\section{ii) Restructuring Nonprofit Sector Funding}

In order to understand the nature of the restructuring process in the nonprofit sector we need to gain an appreciation of its funding patterns. It is important to note that about $60 \%$ of all funds from nonprofit organizations come from government sources, with provincial governments contributing the lion's share (Eakin 2001: ii; Canada West Foundation 1999b: 2). Social service oriented nonprofits appear to be even more dependent upon state financing. In Ontario, for instance, social service nonprofit organizations received some $89 \%$ of their funding in the $1990 \mathrm{~s}$ from the three levels of government (Eakin 2001: 5) ${ }^{6}$. Significantly, it is the provincial state, by a wide margin, that is the most important source of funding dollars for nonprofits. Only some $15 \%$ of nonprofit financial resources are derived from private giving, with individual contributions outpacing corporate by a wide margin. The remaining $25 \%$ is raised by other means but largely through fees for services (Eakin 2001: ii; Day and Devlin 1997: 16).

Governments have not only cut back on their levels of funding but, and we would argument more importantly, they have changed the nature of funds they provide to the nonprofit sector. In short there has been a displacement of core or base funding for "contract funding". Contract funding involves "the purchase of defined services with specified outputs and closely controlled funding, usually accompanied by increased accountability requirements with little or no flexibility in program delivery or funding" (Eakin 2001: i). Additionally there is often the requirement for nonprofit organizations to come up with "matching contribution funding" from other sources (Eakin 2001: i).

Contract funding was perfected in New Zealand and Britain, under Thatcher, and is guided by a neoliberal political philosophy and New Public Management administrative practices. With contract funding there has been a deliberate built-in under-funding of nonprofit organizations. The

5 However, it should also be noted that although there are negative aspects of professionalization, especially with respect to its potential to serve as a de-linking mechanism with the nonprofit's community-base and the threats it poses regarding de-personalization of services, there can also be some very beneficial consequences. The positive impacts of professionalization relate to its ability to create better procedures to protect clients, especially around issues of confidentiality and privacy policies, its role in ensuring better mechanisms to manage finances, and for standardising services (Owen 2003).

${ }^{6}$ It is important to note that while we have a global sense of the funding of nonprofits with charitable status our knowledge of the other components of the nonprofit sector are very incomplete. Also our knowledge is sketchy about funding patterns at the sub-sector level. 
theory guiding this approach is "that under-funding would allow the public to choose which services to support with their donations. ... 'Contract funding' for defined services enable governments to specify outputs and closely control spending. This type of funding has tremendous appeal; it was seen as bringing the rigours of business to the perceived 'inefficiencies' of service provision among voluntary sector organizations" (Eakin 2001: 2)

A study by Reed and Howe of a sample of nonprofit organizations in Ontario, examining the period 1993-1997, found that most nonprofit organizations experienced income loss due to government restructuring — income losers outnumbered income gainers 2:1 with an average loss to organizations of $\$ 350,000$ (2000: 11). These income declines occurred in the context of significant rising demand for services (2000: 16).

Reed and Howe also report that the surveyed agencies indicated a significant increase in organizational income instability and vulnerability; reduced organizational effectiveness in light of energy expended to maintain income levels; and a 'deteriorated' relationships with government funding agencies in large part because of changing government priorities and funding concerns (2000: 17-18). In terms of funding short falls, it is estimated that current contract funding arrangements with nonprofit organizations, after all real costs are factored in, "is from 7\%-15\% short of actual costs" (Eakin 2002: 8).

Eakin provides an explanation as to how under funding in the voluntary sector has come to be so prevalent:

The introduction of business practices into voluntary sector funding was undertaken at a time when government funders were seeking to reduce and contain their spending. As a result, cost containment, cost reduction and efficiency strategies were given priority focus to the neglect of other business practices that might benefit and build the contractor organization. The process has been a 'cheery picking' of business and charitable practices and the resulting funding formula has proved challenging for voluntary sector organizations. Many now find themselves with little or no reserves, thereby reducing their capacity to manage cost changes while operating programs year after year that are routinely funded below cost recovery" (2002: 7).

It is also clear that reliance on increased volunteering can not make up for funding shortfalls. For one there is increased demand and fewer available volunteers. In fact, the latest national survey of volunteering reveals that between 1997 and 2000 there were 1 million fewer volunteers in Canada (Hall, et. al. 2001: 11). Also agencies are finding it increasingly difficult procuring resources to make good use of volunteers, and many agencies require professional services that can not be delivered by volunteers (Reed and Howe 2000: 18-19). Furthermore, the resources extended by many nonprofits to accommodate the "forced volunteering" programs of provincial governments, such as workfare, has greatly complicated the situation. Many nonprofits are now less capable of taking on genuine volunteers because their volunteering training resources 
are absorbed in state driven forced volunteering initiatives.

Funding stress can not be easily made up from other nongovernmental sources because there is greatly increased nonprofit competition for these resources and quite a limited pool to draw from. It has been estimated that a $1 \%$ reduction in government funding would take an additional increase of $50 \%$ from the corporate sector to make up the difference (Shields and Evans 1998: 94). Moreover, there is a question as to whether it is beneficial for smaller agencies to spend resources on slick marketing campaigns; such an approach may not fit with the agency's volunteer image and such campaigns are very resource intensive (Reed and Howe 2000: 19-21). Many nonprofit organizations simply lack the "capacity to sustain fund-raising efforts" (Eakin 2001:3).

With regard matching funding requirements Eakin has identified additional factors that add to the burdens of community agencies.

Although matching contribution funding has obvious advantages for the funder, the practice vastly increases the 'noise' in the charitable sector as projects need to be reviewed by more and more funders. It also significantly increases the effort required by voluntary sector organizations because multiple funders need to be approached for every project. Time pressures and different grant deadlines further complicate the challenges for voluntary sector organizations as they put together 'packages of funding' for each project. Voluntary sector organizations, of course, already juggle different funders for different programs" (2001: 3).

\section{iii) Growing Sources of Stress}

The nature of restructuring in the nonprofit sector has strained the capacity of many community organizations to their very limits. Nowhere have these pressures manifested themselves more acutely than in the nonprofit workforce. One of the greatest sources of stress for the nonprofit sector is the result of both increased workloads and the changing nature of their work. Some of the key factors that have influenced the new world of nonprofit work are: an environment of increased competition, need to work in multi-partner projects, increased accountability reporting, fewer committed and flexible volunteers, clients with more complex problems, and the need to be computerized. The norm is increased demand, without an increase in staff to match these needs. Generally speaking, agencies are doing more for less (Reed and Howe 2000: 21-22).

A study of the job quality in the nonprofit sector reveals that workers in the sector are on average considerably older, more likely to be employed in contingent jobs, better educated, enjoy fewer fringe benefits, bear heaver workloads, and managerial, professional and technical/trades earn \$2 to \$4 per hour less than those in the for-profit sector (McMullen and Schellenberg 2003). In this regard the Canadian Policy Research Networks have come to the following disturbing 
conclusion: "Government off-loading has meant increasing demands on the sector. But, resources may not be adequate for the new responsibilities. Workload problems, stress, work/life conflict, job insecurity, lower pay and benefits and a high level of dissatisfaction are all warning signals" (2003: 2). The provision of publicly provided social services though the mix social economy in Canada has long been made possible though "the sacrifices of exploited staff". With the movement toward intensified alternative service delivery of social provision through the nonprofit sector this tendency has been amplified. And while it is the case that "helping people is a reward in itself, it does not compensate for low wages and lack of benefits" (Canada West Foundation 2000: 6). Given this situation the problem of retention of quality staff in the sector will become increasingly significant and difficult in the future.

In the Reed and Howe's (2000:27-28) Ontario study, most of the respondent organizations were either restructuring, amalgamating, or downsizing — or saw these as imminent. Moreover, the study found that resource reductions were $\boldsymbol{N O T}$ the major concern of the organizations surveyed, rather it was the manner that funds are now provided to voluntary organizations; i.e., contract funding (Reed and Howe 2000: 45-48) ${ }^{7}$.

\section{iv) “Accountability" and the Redefining of the Basic Mission of Nonprofits}

In its most basic form "[a]ccountability is an obligation to explain how a responsibility for an assigned task has been carried out" (Canada West Foundation 1999b: 8). The issue for the nonprofit sector is the greatly expanded scope of responsibilities, and a shift in focus as to what parties the agency is accountable in terms of its basic mission as well as the quality of services provided.

Much of the attempt to restructure the welfare state has been justified on the grounds of enhancing efficiency and accountability. The responsibility for social welfare has been one shared between the state, the private sector and nonprofit organizations, but in the modern period with the state taking a leading role. The contemporary effort to reinvent the welfare state is about recasting this configuration of state-society sharing responsibilities for social welfare. In particular, the goal has been to download many responsibilities onto the family and the nonprofit sector with the contention that this will relieve state fiscal burdens and increase efficiencies (Burke 2000: 179-181).

The issue of accountability has been pushed to the fore as the nonprofit sector undergoes this process of structural adjustment. As more responsibility has come to be loaded on to the Third Sector nonprofits have come under "greater pressure to improve its organizational performance" (Light 2000: v). As Paul C. Light observes:

${ }^{7}$ This is also one of the findings of a recently released report on financing in the sector (Scott 2003). 
Its funders, be they governments, charitable foundations, or individual givers, have never seemed so insistent about economy and results, while its clients, be they communities or individuals, have never been more demanding about efficiency and responsiveness. How the nonprofit sector does its work is becoming almost as important to funders and clients as what the sector actually delivers by way of goods and services" (2000: v).

In spite of decades of rapid growth and strong overall public respect for nonprofit organizations an impression remains that the sector is not as efficient as its private and government sector cousins. The lean and mean philosophes which so dominated private and public sector management thinking in the 1980s and 90s have come to penetrate deeply into the nonprofit sector (Light 2000: 1,13). It is little wonder, consequently, that charitable organizations so often centre their fundraising messages around the organizational efficiency of their operations as much as they emphasize the philanthropic benefits. In the words of Paul Rutherford: "The big charities employed a particular vocabulary of aid to explain their activities. They talked what is colloquially known as the 'language of business,' promising efficiency and economy: 'Doing good fast and cheap' would be an appropriate slogan" (2000: 117-118). This is a kind of a "Harvard Business School bang-for-the-buck mentality that fails to take into account the subjective, unquantifiable nature of much philanthropic[/nonprofit] work" (Dowie 2001: xv).

A key policy informant with whom we consulted put forward a compelling perspective in this regard:

... I always found the notion of voluntary sector 'inefficiency' curious. Often, in justification of some new, particularly destructive initiative, I would be told that voluntary organizations were inefficient because they did not use the latest management theories in their operations, or did not have a 'bottom line' mentality. This despite the obvious fact that voluntary organizations consistently deliver more outputs per dollar of input than either business or government, and consistently seem able to motivate workers to astonishing levels of effort for low compensation. If only business and government could learn to be equally 'inefficient'.

Julie White, former Executive Director of Ontario's Trillium Foundation before she was fired by the Conservative Government, offers these important warnings about why we should be cautious about attempts to hold nonprofits accountable to the same measure of success that applies to the business sector. As she observes:

And all this has created significant pressure on the sector for 'deliverables'; you know, "what are the numbers?", "what are you able to achieve?" And although I think there are some good benefits in applying business standards to charitable organizations, charities do not have quarterly earnings. Their impact is often long term and harder to define and part of the challenge for us, in the sector, is trying to find effective ways of measuring things. And there is a danger in rushing too quickly to superficial indicators that we think are going to measure our success. 
... Canada doesn't do very well in terms of bringing its various sectors together to learn from each other, and although it is true that the nonprofit sector has much to learn from business, it is also true that the business sector has a great deal to learn from the nonprofit sector, particularly about meeting the needs of conflicting stakeholders, managing and measuring long term impact, and dealing with uncertainty. To say nothing about doing 'more with less' $(1996: 4,8)$.

There appears to be a basic misconception embraced by government and other funders that administrative accountability is one and the same as public accountability - in fact, administrative accountability has replaced to a significant degree public accountability. This is a problematic trend for organizations that are engaged with the public in an ongoing basis, especially community-based organizations.

Another complicating factor is the fact that the accountability of the voluntary sector operates at a number of levels. For example, there is a responsibility which nonprofits owe "to their beneficiaries or clients, members, volunteers, staff, partners and affiliates, donors and funders, and governments, as well as to the general public. But, they are accountable in different ways to these different constituencies" (Panel on Accountability and Governance in the Voluntary Sector 1998: 8). Often these various levels of accountability may conflict. For example, government demands for "efficiency and economy of service" may conflict with client desires for "quality service". Such tensions are not easily resolvable; they make up an integral component of the politics which nonprofit bodies are engaged. The basic concern is that accountability to the state has increasingly come to trump nonprofit accountability to the community.

While these issues are fundamentally political and even moral or ethical in their nature in terms of our notions of democracy and public accountability - they have enormous practical impacts for the NGO sector. The new accountability mechanisms not only limit autonomy; they are also very costly. The senior researcher for the Voluntary Sector Initiative has estimated that the cost of the "new accountability regime" for nonprofit service providers may be as high as $20 \%$ of the value of their awarded contracts - a figure rarely acknowledged in the award itself. In the light of these findings Susan Phillips has called for a far more elastic accountability system (Phillips 2002). In a similar vein, a survey of Ontario nonprofit directors have forcefully argued that newly imposed government evaluation requirements have had the unintended effect of actually reducing the ability of agencies to service clients because of the considerable amount of organizational resources they consume in their execution (Reed and Howe 2000: 31). In terms of governance the new contractual terms for service delivery can become "administrative mechanisms to maintain state control over third parties. ... While this issue may appear to be purely administrative, in reality it is political because our frameworks for evaluation are directly linked to our visions of accountability in a democratic society" (Omidvar and Richmond 2003: 8; also see: Evans and Shields 2002).

Further confusion and greater practical problems flow from the current habit of various funders to confound 'accountability' with 'evaluation'. While it is both possible and desirable for a 
particular agency to provide a reasonable level of accountability for publicly-funded service provision; it is simply impossible, at the agency level, to provide true evaluation of the long-term outcomes of their services. The very methodology of such evaluations requires resources and expertise devoted to an examination of macro factors such as changing labour market conditions and population demographics. The confounding of notions of 'accountability' and 'evaluation' places an impossible burden on NGOs, and institionalises the funders' abandonment of responsibility for providing the necessary resources to evaluate the long-term outcomes of publically-funded social services (Chambon and Richmond 2001; and Howarth 1998).

It is essential that this discussion not be interpreted as a refusal of the NGO sector to be accountable for their use of public funds. In fact in the social service sector both funders and NGOs are moving towards an evaluation perspective based on the "logic model", and community agencies, within the limits of their resources, are taking responsibility for developing appropriate accountability systems that meet the needs of their various funders. But funders must also recognize that one or more accountability systems do not constitute an evaluation framework. The development of appropriate accountability systems ultimately depends on a broader evaluation perspective incorporating the goals and complexities, in the case of ISAs, of settlement services in Canada. True public accountability demands not only that we implement accountability systems within a suitable evaluation framework but also that such systems be scientific, appropriate and cost-effective.

While the full range of practical implications that flow from this perspective are beyond the scope of this paper, some essential elements must be noted:

C Funders must assume responsibility for providing NGO service organizations with the necessary resources to implement appropriate systems of accountability and to track the kind of short- and medium-term service outcomes that contribute to more global evaluation.

C Funders must also assume their responsibility for providing the necessary resources and coordination (e.g. with academics and evaluation experts) to provide more global evaluation of service outcomes.

C NGOs involved in service delivery require a single, agency-specific system of evaluation and accountability that corresponds to the agency mission as well as the administrative resources of the agency and the accountability requirements of multiple funders; they cannot continue to assume the burden of providing multiple and changing reporting systems to multiple funders.

C Funders and agencies alike require training in scientific and resource-efficient methods of accountability and evaluation; the desire to "count and evaluate everything" which has developed along with wide-spread computerization must be combated; systems of sampling and the use of qualitative methods must be validated and promoted. 
C Ethical issues remain fundamental to professional delivery of social services; the funders' legitimate concerns for accountability cannot be confounded with an intrusion on the principle of client confidentiality.

Finally, the questions of accountability and evaluation systems are ultimately political and as such must be subject to public debate, rather than negotiated privately and separately between individual agencies and the funders of particular programs. Within this debate there are a number of issues of terminology that currently provide more confusion than clarity with respect to basic issues of public policy. We have already noted the ambiguity of various notions of "accountability", as well as the confusion of "accountability" with "evaluation", but other forms of labelling with ambiguous meanings also require examination.

Consider for example the use of the term "voluntary". For the NGO sector it refers to the community basis of their support and their governance, while for funders it often appears to denote a sector that can be pressured to continually do "more with less". Similarly the terminology of "professionalisation" for the NGO sector refers to the raising of the level of service quality and related compensation, while for funders it appears all to often to imply conformity with externally-imposed obligations at lower costs. Consider as well the increased tendency for governments and funders to itemize services as standard 'unit of service' (Reed and Howe 2000: 29-30), irrespective of the acute needs associated with gendered or racialised status or refugee newcomers, for example. Consider finally the current redefinition of community agencies as "service providing organizations" or SPO's, rather than NGOs with a mission that includes community education, civic engagement, and advocacy.

\section{4) Impacts on the Settlement Sector}

The impacts of this restructuring of the NGO sector can be seen clearly with respect to the current situation of community-based immigrant service organizations (ISOs) and the general crisis of settlement services in Canada. In this respect we must note that it is a mistake to conclude that the success or failure of newcomers is solely dependent upon the kinds of qualities and skills they bring to their host country. In fact, the institutions that immigrants encounter upon arrival play significant roles with respect to how successful their integration into society is (see: Reitz 1998). Two such central institutions are the labour market and publically assisted social service support systems.

Labour markets are the prime mechanisms through which immigrants bind themselves to their new society and by which they are able to build standing within the host's social structure. Social service support systems, including settlement services, are assets that can be drawn upon to assist individuals and families in establishing themselves in the new country, as well as when unanticipated social and economic dislocation occurs. The problem is that both these key institutions have undergone restructuring that have compromised their integrative capacities. 
Broadly conceived, settlement services for immigrants and refugees should be seen as part of the social service/general welfare supports offered by the state. The services can be broad, ranging for initial reception services such as food, clothing and shelter and orientation about the host country, to longer term services such as language instruction, assistance in locating affordable housing, and job search and skills upgrading. The purpose of settlement services is to facilitate as rapid and painless integration into Canadian society as possible (Simich 2000: 10-12; and Omidvar and Richmond 2003: 7). Unfortunately while cuts have been experienced at all stages of service provision, it is the mid-term and longer range settlement-focused services that have been most significantly and negatively impacted by the cuts (Omidvar and Richmond 2003: 8).

In Canada the three levels of government and the nonprofit sector are involved in a complex web of relationships that determine the nature and quality of settlement service delivery. The bulk of services are delivered by the ISOs with support from a variety of funders. In Ontario, for example, financial support for nonprofits providing such services likely peaked in 1994 at about $\$ 70$ million. The province contributed about $42 \%$ of such funding, with $35 \%$ federal, $8 \%$ municipal, 7\% United Way and the remaining 8\% from other charitable sources (Richmond 1996: 3-4).

These complex relationships have important constitutional and jurisdictional elements that impact directly on the crisis of settlement in Canada. For example the failure of the Federal Government and the Province of Ontario to yet come to an agreement on sharing financial responsibilities for settlement services, as has occurred in other provinces, has resulted in funding instability and large service gaps. And because the Federal Government can not constitutionally deal directly with the municipal governments without provincial approval, in spite of the overwhelmingly urban character of the settlement process, settlement service support has been further compromised (Mwarigha 2002: 12).

The effects of cutbacks and NGO restructuring have been particularly dramatic in Ontario. In 1995 the Province of Ontario revamped its settlement program, cutting it by almost 50\%. The province also shifted away from core funding to nonprofit service providers toward competitively tendered service contracts, as did the federal government (Simich 2000: 7). At the same time the Ontario Government also closed its three Ontario Welcome Houses which had provided comprehensive settlement services, including translation and interpretation no longer readily available. Another general program eliminated in 1995 was the provincial Multilingual Access to Social Assistance Program (MASAP), which helped clients receive social assistance (Simich 2000). During the same period the Ontario Government eliminated or overturned a variety of programs and legislation promoting employment equity and supporting anti-racism.

Another important area of stress has been that of employment training and job placement services. Given the appearance of greater employment barriers for recent waves of immigrants and difficulties around employer recognition of foreign obtained skills, job experience and education credentials employment services have become ever more critical. Yet these immigrant services 
like others have been subject to cutbacks creating significant shortages, as demand has soared (Simich 2000: 12). Furthermore, restructuring of Employment Insurance (EI) and EI-based programs have negatively impacted on immigrant access to employment supports. Ironically one of the more important integration resources - immigrant employment services - has been compromised by neoliberal restructuring (see: Shields 2003).

As well the restructuring of broader-based social programs have disproportionately impacted immigrant communities, including program cuts to social assistance, child care, public housing, public health and English as a Second Language (ESL) classes in public schools. For example, "Toronto has lost $60 \%$ of its ESL teachers in the past five years owing to shortfalls in the province's funding formula. The City's drop in ESL teachers is twice that of any other municipality in Ontario" (Clutterbuck and Howarth 2002: 51).

While many ISOs maintained their services and even expanded their funding in this difficult environment, the survivors have generally been the larger multi-service organizations possessing greater administrative resources to devote to the challenges of restructuring. Indeed we seem to be witnessing a kind of growing monopolisation within the NGO immigrant services sector, and a consequent reduction of the diversity of service alternatives. Newly-arrived groups, such as the various African communities, have experienced great difficulties in establishing culturally- and linguistically-appropriate services; and the variety and capacity of service-specific agencies (serving, for example, abused visible minority women) has been greatly reduced. As well, community groups dealing with the cultural and recreational needs of newcomers have experienced growing difficulties because of the growing challenge of finding community space due to increased user fees and reduced access to schools in the province of Ontario. The overall effects of restructuring are "... that many community-based providers of settlement services, particularly the smaller 'ethno-specific' agencies, have been forced to curtail their services drastically or even to close their doors. Those that are still functioning are operating under conditions of extreme stress due to a combination of overloaded service demand and limited funding" (Omidvar and Richmond 3003: 8).

A third element of the settlement process, along with social services and labour market integration, is that which we might identify as "social inclusion" or the degree to which newcomers feel welcomed and accepted in their new homeland. In this respect the ISOs and their umbrella organizations such as the Ontario Council of Agencies Serving Immigrants (OCASI) and the Canadian Council for Refugees (CCR) have played a vital role in promoting equity and combatting racism and anti-immigrant attitudes. As with the NGO sector in general, however, the capacity of the ISOs to maintain and develop this advocacy work is severely compromised by the process of restructuring and the climate of crisis in the settlement sector.

Overall the neoliberal restructuring of nonprofit services has caused a crisis in the sector, as providers are forced to do "more with less". In the process programs have been eliminated, service quality has deteriorated, and many smaller agencies have been forced to close (Evans and Shields 2002). Frontline support for immigrants has been gravely compromised, as has the 
capacity of immigrant serving agencies and their networks to advocate on behalf of Canada's newcomer communities.

\section{5) Concluding Observations: Implications for Democratic Governance}

\section{i) Restoring the NGO Capacity for Advocacy}

It is clear from the preceding analysis that the move to "contract" funding and the associated adoption of new accountability mechanisms has compromised the independence of nonprofit organizations, which are increasingly dependent on limited, short-term and restrictive grants for services. It is much less clear that the new environment has actually improved the quality of service delivery. It is quite evident, however, that basic components of the fundamental missions of NGOs - their capacity for community development and civic education based on their advocacy role - is severely compromised. We have tried to demonstrate in this paper that the fundamental threat to advocacy lies not only in the reduction of funding and related stresses as in the changing conditions of funding. The little fingers of the state now extend deep into the operations of nonprofit organizations, intensifying the work load of already heavily stretched organizations, compromising their autonomy, and working against a vibrant independent civil society

In the short to medium term we need a response to this situation that is both principled and pragmatic. Most importantly the funders of various types and at different levels of government need to recognize their responsibility to put into place a more balanced funding system, one that does not put all the funding eggs, if you will, into the "service contract" funding basket. As well we must reduce the stress on NGO service providers by restoring long-term or "core" funding with adequate provisions for administrative support and infrastructure.

Agreements on accountability mechanisms must also respect the autonomy of community-based organizations and take account of actual capacities and of scientific notions of evaluation. In short, funders must return to their public obligations to financially support the missions and the long-term viability of the NGO sector, rather than tailoring their funding criteria exclusively to immediate service needs and short-term projects mandated by government bureaucracies.

Attempts by neoliberal influences to move third sector organizations toward a market to function more like businesses — rather than a community-based model of operation represents a profound transformation. The movement away from public service values to market values, at

8 For an extended discussion of the democratic implications of existing partnership relationships between government and the nonprofit sector in Canada see Evans and Shields (2002); Shields (2002) http://www.ryerson.ca/ORS/showcase/sahota shields.pdf; and Shields and Evans 1998). A more general treatment of the relationships between voluntary organizations, government and new governance structures is offered by Brock (2003). 
all levels of society, represents a disturbing trend. The dangers of this approach is captured eloquently by Robert Ware.

Communities are the place for public moral activity, while markets are the place for private economic activity. Communities, at their best, foster recognition, care and co-operation. Markets foster anonymity, independence and competition. Communities are considered the place for openness, security and trust. Markets are the place for secrecy, insecurity and distrust ... Communities look for dignity and equality. Markets look for fitness and success. ... The problem is that our society is awash with markets but in need of substantive community with public values (1999: 307).

Some signs of progress have emerged in the recent years. In Quebec, the NGOs have concluded several years of negotiation with the Quebec government with formal agreements recognizing the importance, vitality and autonomy of the community sector (Québec, 2002) ${ }^{9}$. At the Canadian Federal level the Voluntary Sector Initiative is developing codes of best practices, including those governing funding, to which nonprofit service providers and Federal Government contractors are expected to abide. If this initiative is taken seriously by funders at all levels of government it could provide an opportunity to transform one-sided controlling 'partnership' arrangements into more meaningful and collaborative ones. To date, however, it is not clear how, or indeed whether, these principles will be integrated into the day-to-day practice of funding negotiation that shapes and limits the future of the NGO sector ${ }^{10}$.

\section{ii) Research and Policy Analysis}

In the longer term, however, the search for solutions depends at least partially on the development of greater theoretical and conceptual clarification with respect to the nature and role of the "third sector" in Canadian society. Recently we have seen the revival of survey research and policy analysis in this area, a welcome addition to a subject which we believe to be under-studied

9 The community capacity building model of nonprofit sector state support is one that is strongly rooted in the Province of Quebec's relationship to the community sector through its 'social economy' initiatives (see: Noël 2002; Vaillancourt and Tremblay 2002; White 2001; and Lêvesque and Ninacs 2000).

${ }^{10}$ See Philips (2001) for a discussion of the implication of the Accord for the nonprofit sector and the Federal Government. Moreover, it must be noted that in terms of funding arrangements with the nonprofit sector as a whole, the Federal Government is considerably less important than Provincial Governments. 
and generally neglected in policy debate (CPRN 2003; Eakin 2001; Eakin 2002; and Reed and Howe 2000). This recent work needs to be fully mined for the new information available, and the policy implications should be explored in depth. Discussion about this work could also provide an opportunity to explore some of the problems of terminology that compromise our conceptual understanding — such as so-called "voluntary" organizations that provide research and policy analysis and public education, as well as essential social services, with paid staff, and the alleged "special interests" of groups that advocate on behalf of a majority of Canadian citizens.

It also seems necessary to probe more deeply into the motivations of government and the attitudes of public servants and politicians with respect to changing conditions of NGO funding. In this paper we have presented what we believe to be the dominant motivating force: the deliberate and prolonged restructuring of social service delivery as a product of neoliberalism and the crisis of the welfare state. Other explanations however may be relevant. One (anonymous) senior civil servant with experience in Ontario has suggested that politicians are deeply threatened by what they perceive as the rivalry of public interest groups in alliance with government bureaucrats, and that the Progressive Conservatives in Ontario profited from this conflict to inflict their damage on social services and community organizations. Some elements of this explanation are given credibility by the fact that a recent federal parliamentary study (Bennett et al. 2001) focused, among other issues, on the contradiction between accountability to government bureaucrats and accountability to the federal Parliament. Analysis of the perceptions and motivations of elected politicians as well as government functionaries seems therefore a relevant topic to pursue more deeply in relation to our understanding of NGO restructuring.

Finally, and on a deeper level again, if we are to fully confront the issues raised in this paper we must examine more closely the means by which public interest issues are represented, and the types of resources necessary for effective representation, within the vast array of nongovernmental organizations in Canada. While there is no doubt that these forces as a whole provide an essential counterweight to government and the popular media, it is less clear that the current structuring of their work is the most effective. Presuming adequate funding for community development and popular education, should there at the same time be more separation of this funding between service functions and roles of community development and civic engagement? This seems a risky but nevertheless vital question to address at a time when the various levels of government in Canada continue to bemoan the "democratic deficit" while slashing funding for those independent advocacy NGOs that still survive. 


\section{Sources}

Bennett, Carolyn, Donald G. Lenihan, John Williams and William Young. 2001. Measuring Quality of Life: The Use of Societal Outcomes by Parliamentarians (Ottawa: Library of Parliament).

Brock, Kathy L. 2003. "The Nonprofit Sector in Interesting Times: An Introduction Plus". The Nonprofit Sector in Interesting Times: Case Studies in a Changing Sector. Kathy L. Brock and Keith G. Banting, eds. (Montreal: McGill-Queen's University Press).

Burke, Mike. 2000. "Efficiency and the Erosion of Health Care in Canada". In Restructuring and Resistance: Canadian Public Policy in an Age of Global Capitalism. Mike Burke, Colin Mooers and John Shields, eds. (Halifax: Fernwood).

Burke, Mike and John Shields. 2000. "Tracking Inequality in the New Canadian Labour Market". Restructuring and Resistance: Canadian Public Policy in an Age of Global Capitalism. Mike Burke, Colin Mooers and John Shields, eds. (Halifax: Fernwood).

Canadian Council on Social Development. 2003. Census Shows Growing Polarization of Income in Canada: Census Analysis (Ottawa: Canadian Council on Social Development, May 16); http://www.ccsd.ca/pr/2003/censusincome.htm

Canada West Foundation. 2000. "Building Better Partnerships: Improving Relations Between Governments and Non-Profits", Research Bulletin, No. 5, September (Calgary: Alternative Service Delivery Project, Canada West Foundation).

Canada West Foundation. 1999a. "Great Expectations: The Ideal Characteristics of Non-Profits", Research Bulletin, No. 3, June (Calgary: Alternative Service Delivery Project, Canada West Foundation).

Canada West Foundation. 1999b. "Strings Attached: Non-Profits \& Their Funding Relationships With Government", Research Bulletin, No. 4, September (Calgary: Alternative Service Delivery Project, Canada West Foundation).

Canadian Policy Research Networks (CPRN). 2003. "The Nonprofit Sector: Struggling to Make Work Pay”, News Release, (Ottawa: Canadian Policy Research Networks Inc., January 10).

Chambon, Adrienne and Ted Richmond. 2001. "L'évaluation des services d'établissement pour les personnes immigrantes et réfugiées: Enjeux conceptuels et méthodologiques", Cahiers de recherche sociologiques: L'évaluation sociale un enjeu politique (35 Spring, Département de sociologie, UQAM). 
Clutterbuck, Peter and Rob Howarth. 2002. Toronto's Quiet Crisis: The Case for Social and Community Infrastructure Investment, Research Paper 198 (Toronto: Centre for Urban and Community Studies, University of Toronto, November).

Cobb, Clifford, Tedd Halstead and Jonathan Rowe. 1995. "If the GDP is Up, Why is America Down?" The Atlantic Monthly, October.

Collacott, Martin. 2002. Canada's Immigration Policy: The Need for Major Reform (Vancouver: The Fraser Institute, September).

Creese, Gillian. 1998. Government Restructuring and Immigrant/Refugee Settlement Work: Bringing Advocacy Back In (Vancouver: RIIM < riim.metropolis.net $>$ ).

Day, Kathleen M. and Rose Anne Devlin. 1997. The Canadian Nonprofit Sector. (Ottawa: Canadian Policy Research Networks Inc.).

Dowie, Mark. 2001. American Foundations: An Investigative History. (Cambridge, Mass.: The MIT Press).

Eakin, Lynn. 2002. Supporting Organizational Infrastructe in the Voluntary Sector (Ottawa: Voluntary Sector Initiative Secretariat, May).

Eakin, Lynn. 2001. An Overview of the Funding of Canada's Voluntary Sector (Ottawa: Voluntary Sector Initiative Working Group on Financing, September).

Evans, M. 1998. "Behind the Rhetoric: The Institutional Basis of Social Exclusion and Poverty", IDS Bulletin, Vol.29, No. 1.

Evans, B. Mitchell and John Shields. 2002. "The Third Sector: Neo-Liberal Restructuring, Governance, and the Remaking of State-Civil Society Relationships". In The Handbook of Canadian Public Administration. Chris Dunn, ed. (Don Mills, ON: Oxford University Press), pp. 139-158.

Francis, Diane. 2002. Immigration: The Economic Case (Toronto: Key Porter Books).

Galabuzi, Grace-Edward. 2001. Canada's Creeping Economic Apartheid: The Economic Segregation and Social Marginalisation of Racialised Groups (Toronto: Canadian Centre for Social Justice Foundation for Research and Education, May).

Hall, Michael, Larry McKeown and Karen Roberts. 2001. Caring Canadians, Involved Canadians, 2000 (Ottawa: Statistics Canada).

Hall, Michael and Paul Reed. 1998. "Shifting the Burden: How Much Can Government 
Download to the Nonprofit Sector?", Canadian Public Administration, Vol. 41, No. 1, Spring.

Howarth, Rob. 1998. Outcome Evaluation for Neighbourhood Centres. Summary Report: The CNC Outcome Evaluation Initiative (Toronto: Coalition of Neighbourhood Centres).

Jenson, Jane and Susan D. Philips. 1996. "Regime Shift: New Citizenship Practices in Canada", International Journal of Canadian Studies, 14, Fall.

Laforest, Rachel. 2001. "Funding Policy Capacity", Paper presented to the $30^{\text {th }}$ Annual Conference of the Association for Research on Nonprofit Organizations and Voluntary Action (ARNOVA), Miami, Florida, November 30.

Lêvesque, Benoît and William A. Ninacs 2000. "The Social Economy in Canada: The Quebec Experience". In Social Economy: International Debates and Perspectives. Eric Shragge and Jean-Marc Fontan, eds. (Montreal: Black Rose Books).

Light, Paul C. 2000. Making Nonprofits Work: A Report on the Tides of Nonprofit Management Reform (Washington, D.C.: Brookings Institution Press).

Marquardt, Richard. 1998. Enter at Your Own Risk: Canadian Youth and the Canadian Labour Market (Toronto: Between the Lines).

Maxwell, Judith. 1997. "Foreword". In The Emerging Sector: In Search of a Framework. Ronald Hirshhorn ed., (Ottawa, Canadian Policy Research Networks).

McBride, Stephen and John Shields. 1997. Dismantling a Nation: The Transition to Corporate Rule in Canada, second edition (Halifax: Fernwood).

McMullen, Kathryn and Grant Schellenberg. 2003.Job Quality in Non-Profit Organizations, Research Series on Human Resources in the Non-Profit Sector, No. 2 (Ottawa: Canadian Policy research Networks).

Metro Toronto Community Services, Social Planning Council of Metropolitan Toronto and City of Toronto Planning and Development. 1995. 1995 Community Agency Survey of Metropolitan Toronto (Toronto: City of Toronto, May).

Mwarigha, M.S. 2002. Towards a Framework for Local Responsibility (Toronto: Maytree Foundation, January).

Mwarigha, M.S. and Collette Murphy. 1997. Merchants of Care? The Non-Profit Sector in a Competitive Social Services Marketplace (Toronto: Social Planning Council of Metropolitan Toronto). 
Ng, Roxana. 1996. The Politics of Community Services: Immigrant Women, Class and State, $2^{\text {nd }}$ edition (Toronto: Garamond Press).

Noël, Alain. 2002. “A Law Against Poverty: Quebec's New Approach to Combating Poverty and Social Exclusion", Background Paper - Family Network (Ottawa: Canadian Policy Research Networks), December.

Omidvar, Ratna and Ted Richmond. 2003. Immigrant Settlement and Social Inclusion in Canada, Perspective on Social Inclusion Working Paper Series (Toronto: Laidlaw Foundation, January).

Ornstein, Michael. 2000. Ethno-Racial Inequality in the City of Toronto: An Analysis of the 1996 Census (Toronto: Chief Administrator's Office, City of Toronto).

Osborne, David and Ted Gaebler. 1992. Reinventing Government: How the Entrepreneurial Sprit is Transforming the Public Sector (Reading, MA: Addison-Wesley).

Owen, Tim. 2003. "Director, World Education Services Correspondence with John Shields", May 2.

Owen, Tim. 2000. "NGO - Government Partnerships", Journal of International Migration and Integration, Vol. 1, No. 2, Winter.

Panel on Accountability and Governance in the Voluntary Sector. 1998. Helping Canadians Help Canadians: Improving Governance and Accountability in the Voluntary Sector, A Discussion Paper, May; http://www.pagvs.com/helping.html

Phillips, Susan D. 2003. "Voluntary Sector-Government Relationships in Transition: Learning from International Experience for the Canadian Context". The Nonprofit Sector in Interesting Times: Case Studies in a Changing Sector. Kathy L. Brock and Keith G. Banting, eds. (Montreal: McGill-Queen's University Press).

Phillips, Susan. 2002. "The Voluntary Sector Rediscovered: Implications for Citizenship and the Study of Political Science", Department of Political Science Seminar, University of Toronto, October 11.

Phillips, Susan. 2001. A Federal Government - Voluntary Sector Accord: Implications for Canada's Voluntary Sector (Ottawa: Voluntary Sector Initiative Secretariat, February).

Quebec. 2002. Politique Gouvernementale: L'action communitaire (Quebec City: Government of Quebec).

Reed, Paul B. and Valerie J. Howe. 2000. Voluntary Organizations in Ontario in the 1990s, 
Nonprofit Knowledge Base Project Reports (Ottawa: Statistics Canada).

Reitz, J.G.. 1998. Warmth of the Welcome: The Social Causes of Economic Success for Immigrants in Different Nations and Cities (Boulder, CO: Westview Press).

Richmond, Ted. 1996. Effects of Cutbacks on Immigrant Service Agencies: Results of an Action Research Project (Toronto: City of Toronto Public Health Department, September).

Russell, Bob. 2000. "From Workhouse to Workfare: The Welfare State and Shifting Policy Terrains". Restructuring and Resistance: Canadian Public Policy in an Age of Global Capitalism. Mike Burke, Colin Mooers and John Shields, eds. (Halifax: Fernwood).

Rutherford, Paul. 2000. Endless Propaganda: The Advertising of Public Goods (Toronto: University of Toronto Press).

Scott, Katherine. 2003. Funding Matters: The Impact of Canada's New Funding Regime on Nonprofit and Voluntary Organizations, in collaboration with the Coalition of National Voluntary Organizations (Ottawa: Canadian Council on Social Development).

Shields, John. 2003. No Safe Haven: Markets, Welfare and Migrants, CERIS Working Paper, No. 22 (Toronto: Joint Centre of Excellence for Research on Immigration and Settlement Toronto, January).

Shields, John. 2002. "Capturing Civil Society: The Third Sector in the Shadow of the State", Sarwan Sahota Seminar (Toronto: Ryerson University, February 21). http://www.ryerson.ca/ORS/showcase/sahota_shields.pdf

Shields, John and B. Mitchell Evans. 1998. Shrinking the State: Globalization and the "Reform" of Public Administration. (Halifax: Fernwood Publishing).

Simich, Laura. 2000. Towards A Greater Toronto Charter: Implications for Immigrant Settlement (Toronto: Maytree Foundation, September 11).

Social Planning Council of Ottawa-Carleton 2001. 2001. Advancing the Community by Strengthening the Voluntary Sector: Report on the 2001 Community Consultation. (Ottawa: Social Planning Council of Ottawa-Carleton, August 15).

Statistics Canada. 2003. Earnings of Canadians: Making a Living in the New Economy (Ottawa: Statistics Canada) Analysis series: 96F0030XIE2001013; http://www12.statcan.ca/english/census01/products/analytic/companion/earn/canada.cfm

Stoffman, Daniel. 2002. Who Gets In (Toronto: Macfarlane Walter \& Ross). 
United Way of Greater Toronto \& Canadian Council on Social Development. 2002. A Decade of Decline: Poverty and Income Inequality in the City of Toronto in the 1990s (Toronto: United Way of Greater Toronto \& Canadian Council on Social Development).

United Way of Greater Toronto. 1997. Metro Toronto: A Community at Risk (Toronto: United Way of Greater Toronto).

Vaillancourt, Yves and Louise Tremblay. 2002. Social Economy: Health and Welfare in Four Canadian Provinces. (Halifax: Fernwood).

Ware, Robert. 1999. "Public Moral Values, the Fabrication of Communities and Disempowerment". In Citizens or Consumers? Social Policy in Market Society. Dave Broad and Wayne Antony, eds. (Halifax: Fernwood Publishing).

White, Deena. 2001. 'Harnessing a Movement, Taming an Ideology on the State and the Third Sector in Quebec", Isuma, Vol. 2, No. 2, Summer.

White, Julie. 1996. "The Challenge of Governance in a Turbulent Environment", A Symposium of the School of Policy Studies and the Centre for Quality in Governance, Toronto, April 10. 